\title{
A FUZZY LOGIC CONTROLLED DC-DC CONVERTER FOR AN ELECTROLYZER APPLICATION WITH A VOLTAGE DOUBLER
}

\author{
K.Shanthi ${ }^{1}$, U. Rajesh ${ }^{2}$, A. Mallikarjuna Prasad ${ }^{3}$ \\ ${ }^{I}$ EEE Department, St John's College of Engineering and Technology, Yemmiganur, India \\ ${ }^{2}$ EEE Department, St John's College of Engineering and Technology, Yemmiganur, India \\ ${ }^{3}$ EEE Department, St John's College of Engineering and Technology, Yemmiganur, India
}

\begin{abstract}
This paper develops a fuzzy logic controlled dc-dc converter for an electrolyzer application with a voltage doubler. In general day by day usage of power is increasing rapidly but the available resources are exhausting in the near future. Hence we are going for the renewable energy system (RES). It converts the energy into heat or electricity. Electrolyzer is a part of a renewable energy system which converters source power available into hydrogen for fuel cell. But electrolyzer lacks the ability to control the power over rapid changes in input and load, hence a power conditioning system is required to connect the electrolyzer to a system dc bus . Usually a dc-dc converter is used in the most of application. This project deals with the comparison of three soft switched dc-dc converter configurations for an electrolyzer and design of two stage (ZVT boost followed by LCL series resonant converter) with fuzzy logic control. The proposed model has a Zero Voltage switching(ZVS) technique which maintain the soft switching for complete load range. This proposed model is developed and analyzed using MATLAB/Simulink Software and the simulation results obtained justify the accuracy of proposed control technique.
\end{abstract}

Keywords: DC-DC converter, electrolyzer, fuzzy logic controller PI controller, SRC, ZVS, ZVT.

\section{INTRODUCTION}

The main drawback of the electrical system is storage .RES in the form of hydrogen storage overcome the weakness of battery based system. Hence an electrolyzer is needed to convert the electricity into hydrogen. The ability to store energy at times when the supply exceeds demands will be a key to the effective utilization of renewable energy. Because many renewable sources (e.g. wind, solar, tidal) are intermittent in nature, storage is useful. The figure 1 shows the schematic diagram of a RES.

The basic idea is to keep harvesting the energy resource at a steady rate, regardless of the demand. Usually, this results in the most efficient operation. If the demand is less than full capacity, the excess is diverted into storage medium. in the proposed we go for a hydrogen storage which utilizes excess electric power to produce hydrogen and oxygen from water by means of electrolysis. Energy can be retrieved by running them back through a fuel cell.

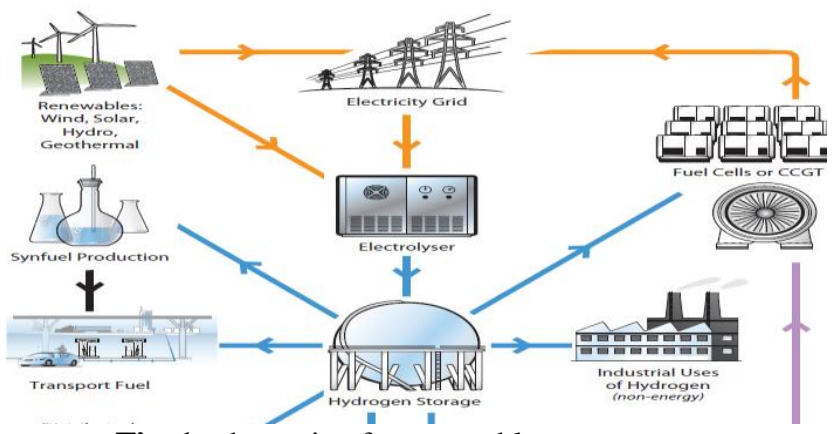

Fig. 1 schematic of a renewable energy system
In this paper we develops a MATLAB/simulink model of three soft-switched high-frequency transformer isolated dcto-dc converter configurations for electrolyzer. Firstly, we compared the three switching configurations of a dc-dc converter. Among them it is shown that LCL type series resonant converter with capacitive output filter is suitable for this application. Due to the wide variation in input voltage and load current, no converter can maintain zerovoltage switching (ZVS) for the complete operating range. Therefore, a two-stage converter (ZVT boost converter followed by LCL SRC with capacitive output filter) is adapted. later a PI and FUZZY logic control was implemented for a closed loop operation and simulation results are compared.

\section{NEED OF A DC-DC CONVERTER}

To achieve proper voltage matching the main components of the system should be connected to the DC-bus of RES via dcdc converter. The electrolyzer is interfaced by help of a stepdown DC/DC converter, while the fuel cell is connected by help of a step-up DC/DC converter.

In principle, any basic power converter topology can be used to design a power interface for a fuel cell and an electrolyzer. Typically, these converters have a high-frequency voltage transformer, which could also perform the function of isolation. The main technology development trend here is to reduce the power losses in the interface converters in order to obtain the highest possible energy efficiency .The following figure 2 shows the need of a DC-DC converter. 


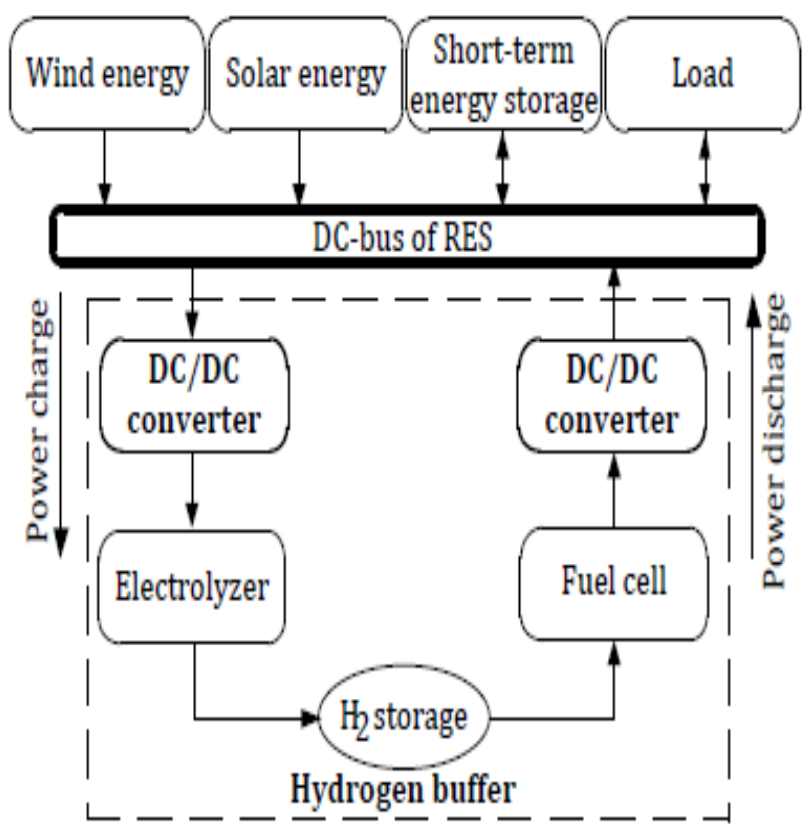

Fig 2 Energy exchange using dc-dc converter

\section{POSSIBLE SOFT SWITCHING}

\section{CONFIGARATIONS FOR THE ELECTROLYZER}

\section{APPLICATION}

Soft switching converters has many advantages over hard switching converters .these soft switching converters had a advantage of reduce voltage/current stress, reduce EMI, reduced switching losses, and allow a greater high frequency in high power applications. There are three major types of HF transformer isolated soft switching converter configurations possible: 1) voltage fed resonant converters 2) current fed resonant converters and 3) fixed-frequency resonant transition zero-voltage switching (ZVS) pulse width modulation (PWM) bridge converters .but current fed resonant converters require HF switches rated at 5-6 times the input voltage which reduces the efficiency. Hence Voltage fed resonant converter with fixed-frequency operation is adopted in this paper. the six soft-switching converter configurations for the electrolyzer application:

1) Fixed-frequency series resonant converter (SRC).

2) Fixed-frequency parallel resonant converter (PRC.)

3) Fixed-frequency series-parallel or $L C C$-type resonant converter (SPRC).

4) Fixed-frequency $L C L S R C$ with a capacitive output filter.

5) Fixed-frequency $L C L S R C$ with an inductive output filter.

6) Fixed-frequency phase-shifted ZVS PWM full-bridge converter.

Among the aforementioned six converter configurations, the SRC and SPRC can operate with the ZVS, only for very narrow variations in supply and load variations in the present application. In the case of PRC, the inverter peak current does not decrease much with reduction in the load current and there is no coupling capacitor in series with the HF transformer. Therefore, the first three configurations are not considered.
Table: 1 Comparison of Converters

\begin{tabular}{|c|c|c|c|}
\hline Problems & $\begin{array}{lr}\text { LCL } & \text { SRC } \\
\text { with } & \text { cap } \\
\text { filter } & \end{array}$ & $\begin{array}{l}\text { LCL SRC } \\
\text { with } \\
\text { inductive } \\
\text { filter }\end{array}$ & $\begin{array}{l}\text { Phase } \\
\text { shifted } \\
\text { PWM } \\
\text { converter }\end{array}$ \\
\hline ZVS range & $\begin{array}{l}100 \% \text { load } \\
\text { to } 10 \% \text { load } \\
\text { minimum } \\
\text { input } \\
\text { voltage }\end{array}$ & $\begin{array}{l}100 \% \text { load } \\
\text { to } 10 \% \text { load } \\
\text { minimum } \\
\text { input } \\
\text { voltage }\end{array}$ & $\begin{array}{l}100 \% \text { load } \\
\text { to } 10 \% \text { load } \\
\text { minimum } \\
\text { input } \\
\text { voltage }\end{array}$ \\
\hline $\begin{array}{l}\text { Duty cycle } \\
\text { loss }\end{array}$ & Not present & Present & Present \\
\hline $\begin{array}{l}\text { Rectifier } \\
\text { ringing }\end{array}$ & Not present & $\begin{array}{l}\text { Present, } \\
\text { requires } \\
\text { snubber }\end{array}$ & $\begin{array}{l}\text { Present, } \\
\text { requires } \\
\text { snubber }\end{array}$ \\
\hline
\end{tabular}

\section{BLOCK DIAGRAM OF A EXISTED SYSTEMS}

The following figure 3 shows the block diagram of a existed system. it consists renewable source input which was given to ZVT boost converter from there it is converted into a high frequency AC using LCL- SRC converter and its output was coupled to a rectifier using HF step down transformer. The DC output of the rectifier is used to feed the electrolyzer plant

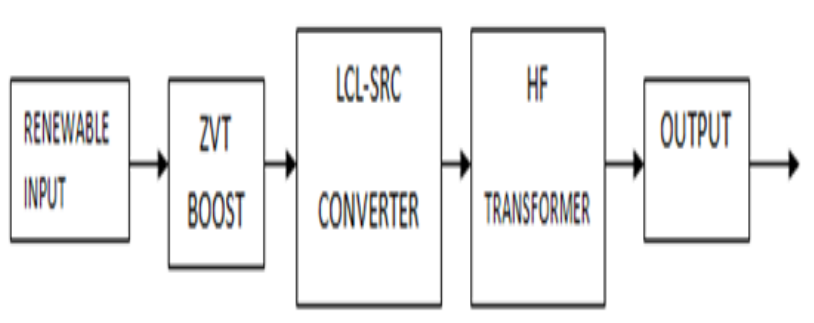

Fig 3 Block diagram of a existed system

\section{BLOCK DIAGRAM OF PROPOSED SYSTEM}

In this proposed system a voltage doubler is placed instead of rectifier, as it performs the rectification and as well as doubles the output voltage .

$$
\mathrm{V}_{\mathrm{o}}=2 * \mathrm{~V}_{\mathrm{out}}
$$

Even though existing two stage boost converter system is operating accurately, for a wide changing load and input sources time to time there is fluctuations in the output.The following figure 4 shows the block diagram of a proposed system. 


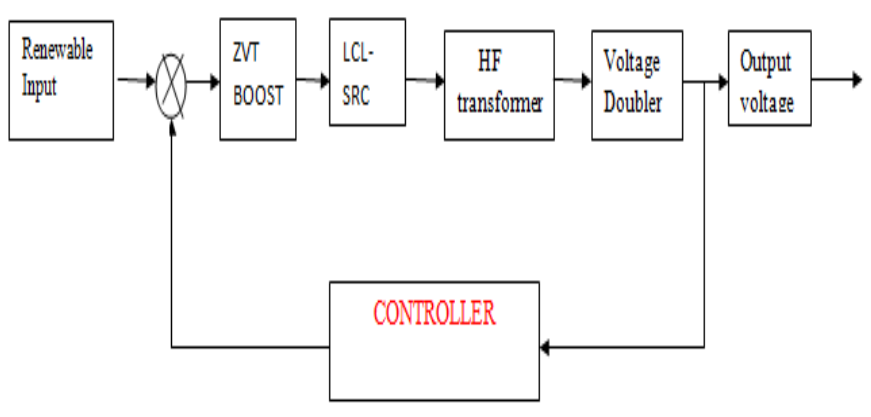

Fig 4 Block Diagram of A Proposed System

\section{RESULTS AND DISCUSSIONS}

MATLAB is a software package for computation in engineering, science, and applied mathematics. It offers a powerful programming language, excellent graphics, and a wide range of expert knowledge. MATLAB is published by and a trademark of The MathWorks, Inc.

\subsection{MATLAB Model for a LCL-SRC with Inductive}

\section{Filter}

The following figure5 shows the MATLAB model of a LCL$\mathrm{SRC}$ with an inductive output filter. And the figures $6,7,8$ shows the input voltage, voltage across $V_{a b}$, output voltage $\mathrm{V}_{\mathrm{o}}$. Their values are given as follows

Input voltage $\quad=40 \mathrm{~V}$

Voltage across $\mathrm{Vab}=40 \mathrm{~V}$

Output voltage $\mathrm{Vo}_{\mathrm{O}}=54$

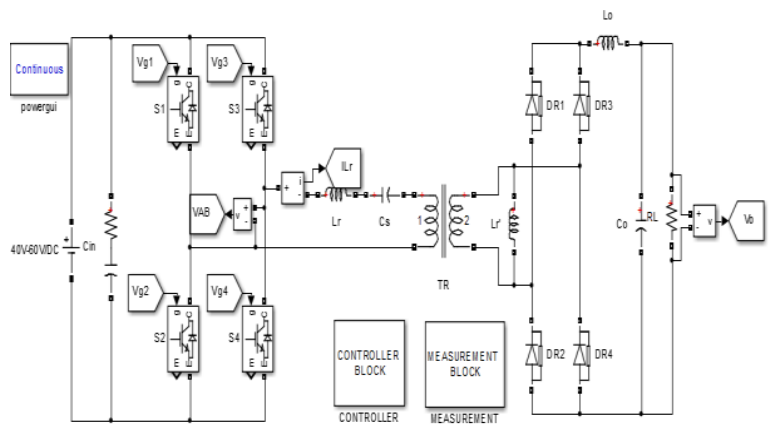

Fig. 5. MATLAB model of a lcl-src with an inductive filter

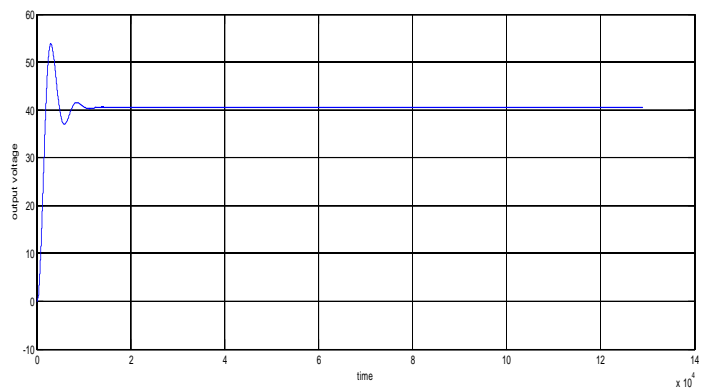

Fig. 6. simulation result showing the output voltage Vo

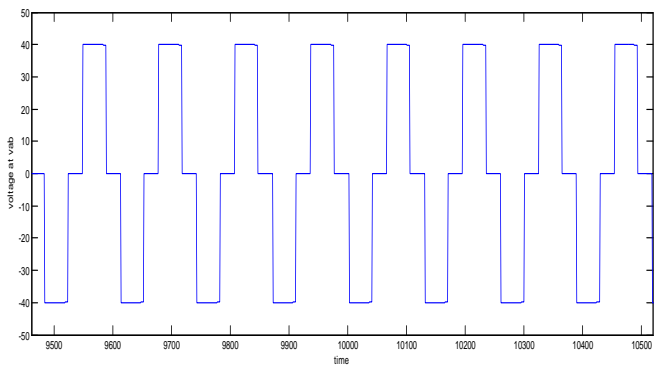

Fig. 7. Simulation result showing voltage vab

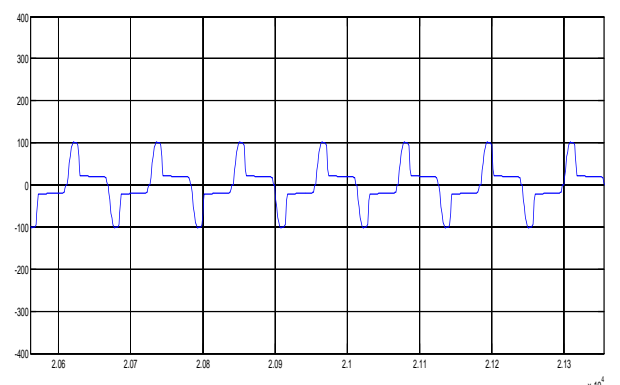

Fig. 8. Simulation result showing inductor current il

\subsection{MATLAB Model for a Fixed-Frequency Phase- Shifted ZVS PWM Full-Bridge Converter}

The following figure 9 shows the MATLAB model of a LCL-SRC with an inductive output filter. . And the figures $10,11,12$ shows the input voltage, voltage across $\mathrm{V}_{\mathrm{ab}}$, output voltage $\mathrm{V}_{\mathrm{o}}$. Their values are given as follows

$\begin{array}{ll}\text { Input voltage }= & 40 \mathrm{~V} \\ \text { Voltage across } \mathrm{V}_{\mathrm{ab}}= & 40 \mathrm{~V} \\ \text { Output voltage } \mathrm{V}_{\mathrm{o}}= & 54 \mathrm{~V}\end{array}$

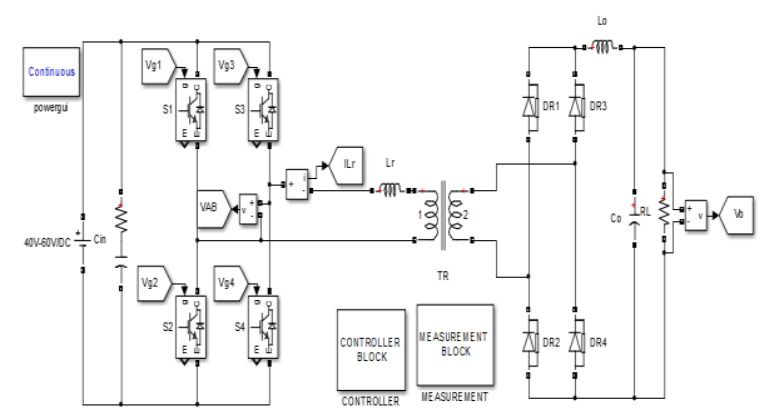

Fig 9 MATLAB model of a fixed-frequency phase-shifted ZVS PWM full-bridge converter

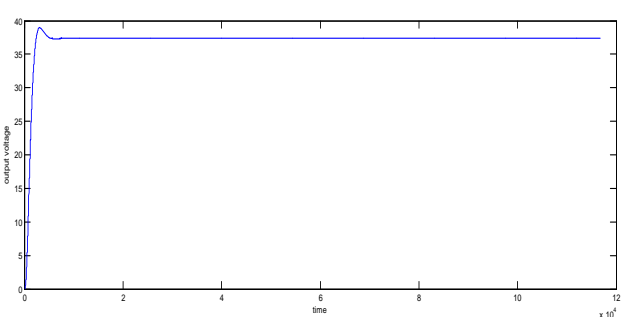

Fig. 10. simulation result showing the output voltage Vo 


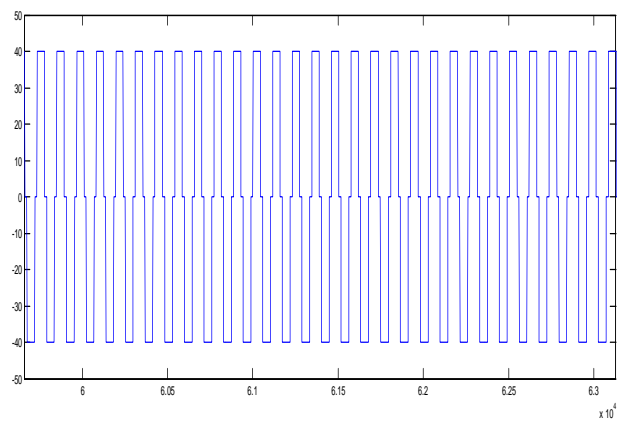

Fig. 11. Simulation result showing voltage vab

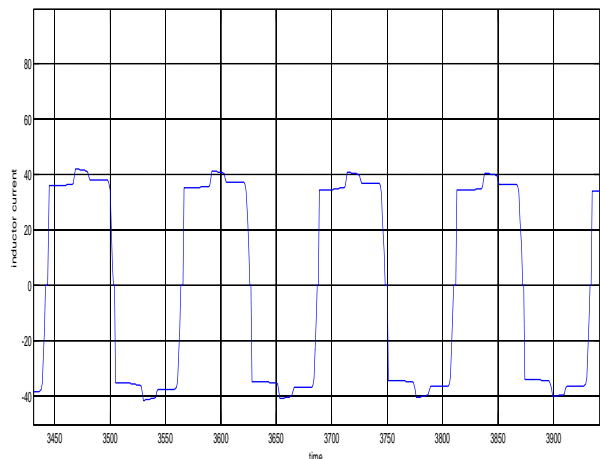

Fig. 12. Simulation result showing inductor current il

\subsection{MATLAB Model for a LCL-SRC with Capacitive Output Filter}

The following figure 13 shows the MATLAB model of a LCL-SRC with a capacitive output filter. And the figures 14, 15,16 shows the input voltage, voltage across $\mathrm{V}_{\mathrm{ab}}$, output voltage $\mathrm{V}_{\mathrm{o}}$. Their values are given as follows

Input voltage $\quad=40 \mathrm{~V}$

Voltage across $\mathrm{V}_{\mathrm{ab}}=40 \mathrm{~V}$

Output voltage $\mathrm{V}_{\mathrm{o}}=54 \mathrm{~V}$

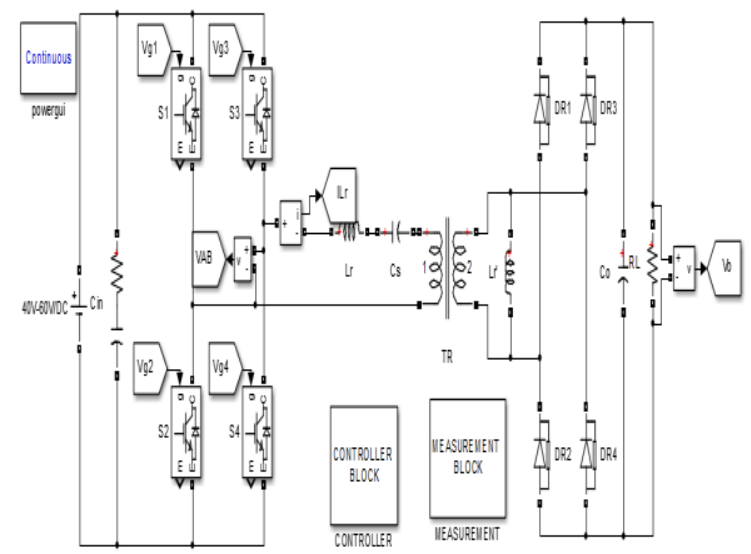

Fig. 13. MATLAB model of a LCL-SRC with a capacitive output filter

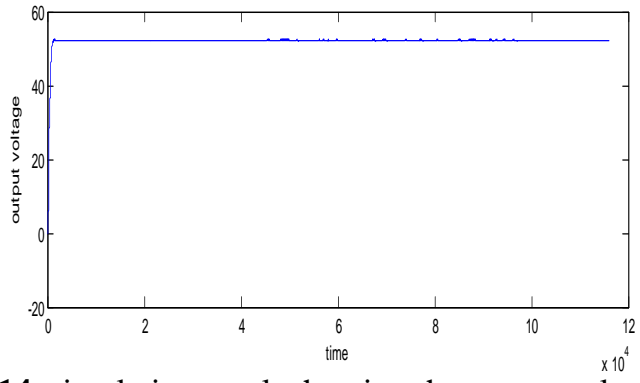

Fig. 14. simulation result showing the output voltage $V_{0}$

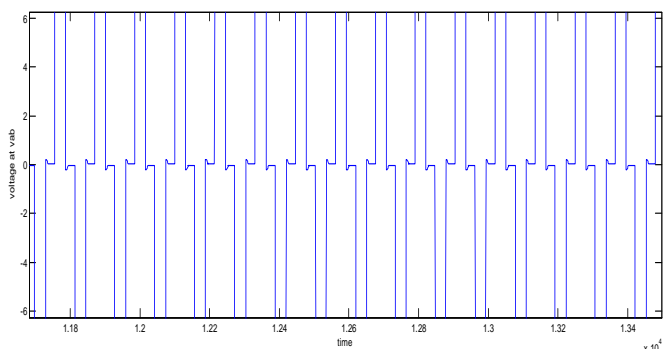

Fig. 15. Simulation result showing voltage vab

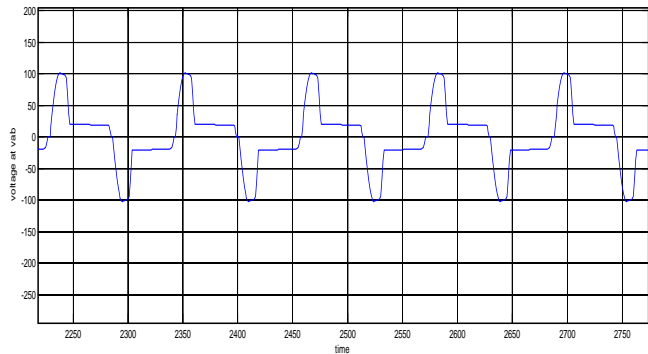

Fig. 16. Simulation result showing inductor current

From the figures 6,10 and 14 it can be say that LCL-SRC with capacitive output filter has a better performance as the peak in the output voltage had reduced to a great extent. and also it maintains the ZVS for changes .

\subsection{MATLAB Model for a Two Stage (ZVT Boost LCL-SRC) Approach}

LCL SRC with capacitive output filter has better performance compared to other configuration, it maintains ZVS for wide change in input voltage. But for wide change in input an extra resonant inductor is required. So a ZVT boost converter is required to boost input. By using this converter the complexity in simplifying the resonant component can be reduced when compared to other approach.

This approach not only achieves ZVS for all the switches but also simplifies the design of $\mathrm{Lr}$ and $\mathrm{Cs}$ resonant components.

The following figure 17 shows the MATLAB model of ZVT boost LCL-SRC with capacitive output filter. And the figures $18,19,20$ shows the input voltage ,voltage across $\mathrm{V}_{\mathrm{ab}}$, output voltage $\mathrm{V}_{\mathrm{o}}$. Their values are given as follows

Input voltage $\quad=40 \mathrm{~V}$ 
Voltage across $\mathrm{Vab}=40 \mathrm{~V}$

Output voltage $\mathrm{Vo}=60 \mathrm{~V}$

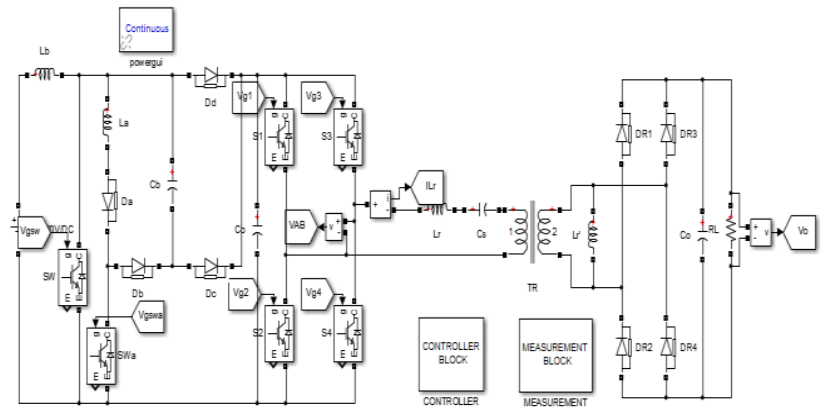

Fig. 17. MATLAB model of a LCL-SRC with a capacitive output filter

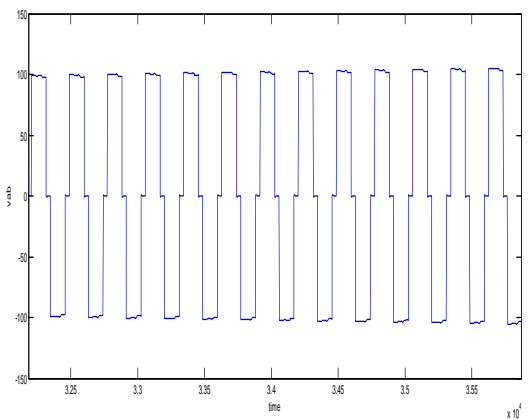

Fig. 18. Simulation result showing voltage vab

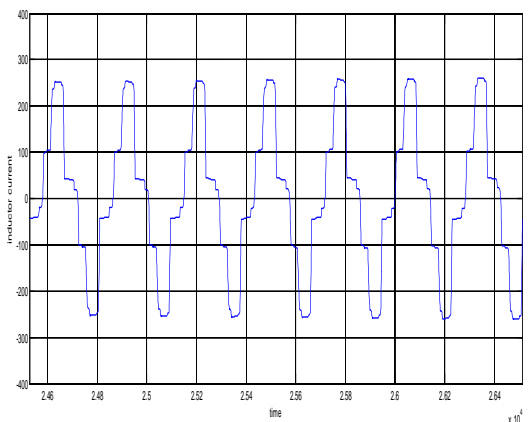

Fig. 19. Simulation result showing inductor current

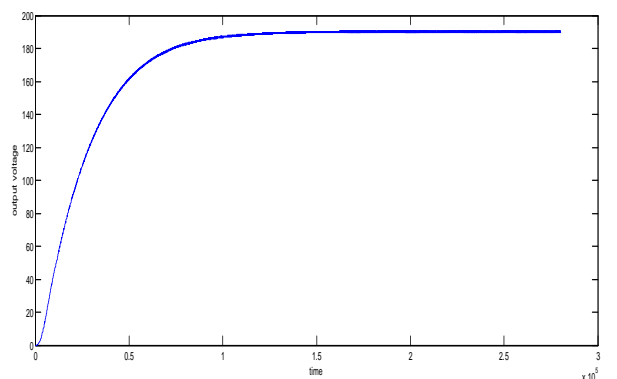

Fig. 20. Simulation result showing output voltage Vo

From the above figure 20 it can observe that smoot output voltage is observed .hence by adopting the ZVT boost at the input side the input is maintained to a constant value hence there by reducing the swithing losses at the inverter

\subsection{MATLAB Model for a PI Controller with Voltage Doubler}

The following figure 21 shows the two stage(ZVT boost LCL-SRC ) with an voltage doubler and a PI controller. At the input side a FUEL cell stack taken as the input source. And the figures 23, 24, 25 shows the input voltage, voltage across $\mathrm{V}_{\mathrm{ab}}$, output voltage $\mathrm{V}_{\mathrm{o}}$. Their values are given as follows

$\begin{array}{lll}\text { Input voltage } & =40 \mathrm{~V} \\ \text { Voltage across } \mathrm{Vab} & =100 \mathrm{~V} \\ \text { Output voltage Vo } & =120 \mathrm{~V}\end{array}$

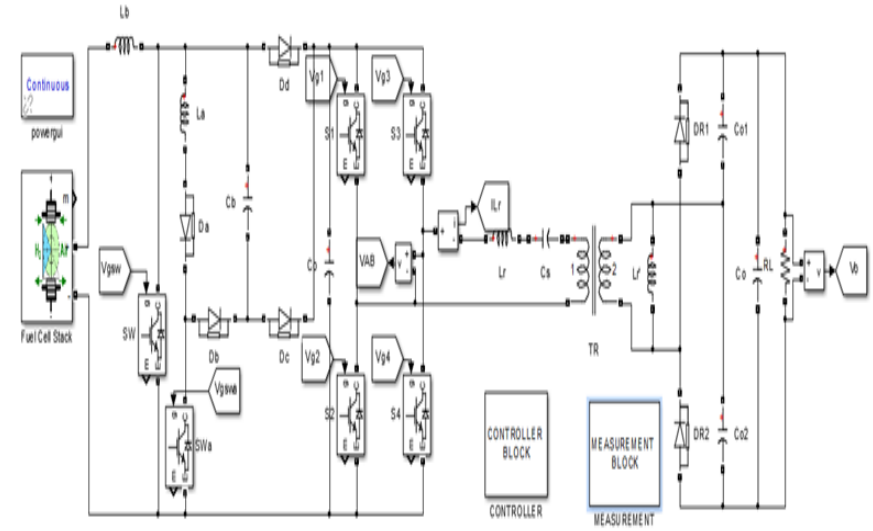

Fig. 21. MATLAB model of a pi controller with voltage doubler

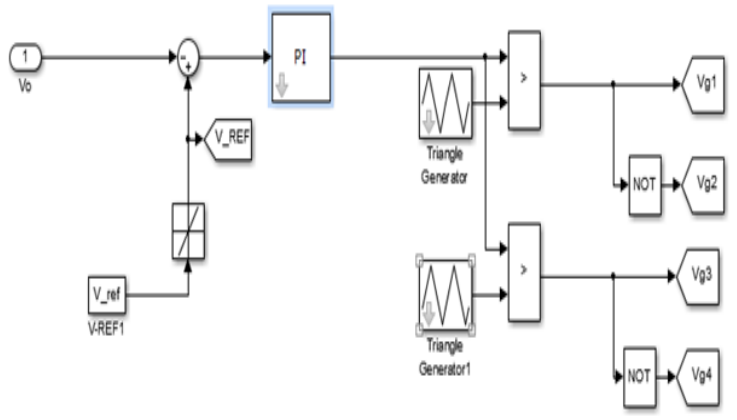

Fig. 22. MATLAB model of a subsystem of a PI controller

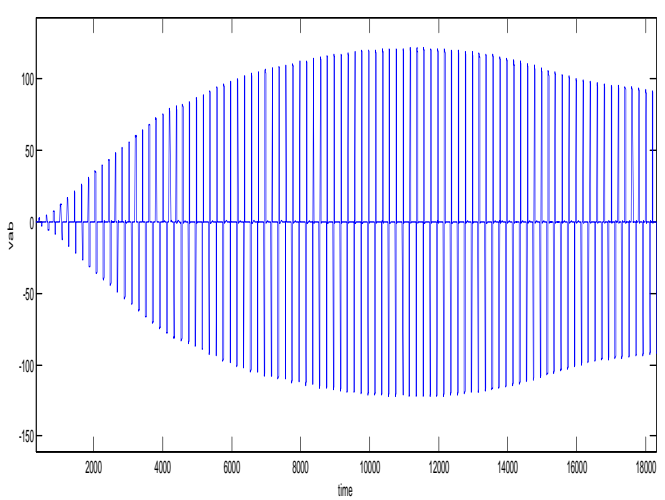

Fig. 23. Simulation result showing voltage Vab 


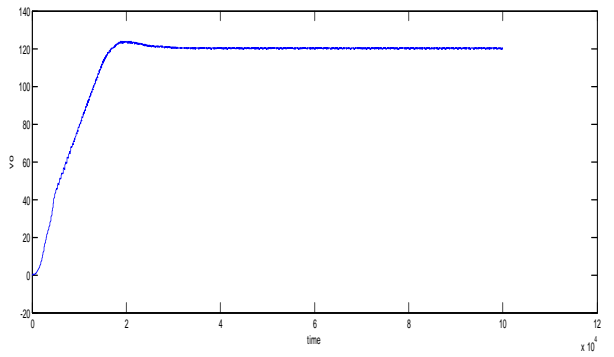

Fig. 24. Simulation result showing output voltage Vo

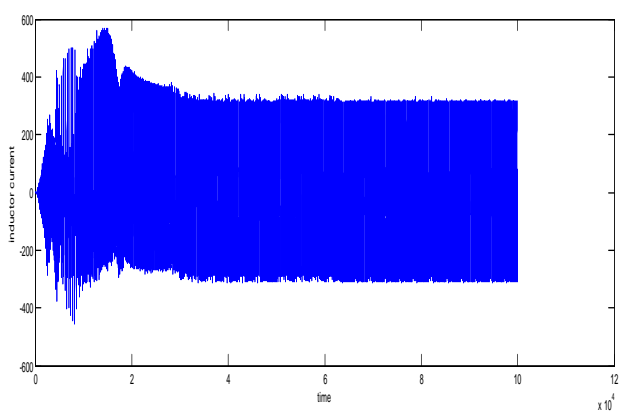

Fig. 26. Simulation result showing inductor current

\subsection{MATLAB Model of a Fuzzy Logic System}

The use of fuzzy logic is attractive for control systems since it enables the use of multiple inputs. Fuzzy logic also enables the description of the behavior of the controller using several rules defined by a set of linguistic variables. Hence, FLC is a promising tool for controlling complex, linguistic based systems. The steps to implement the fuzzy logic controller is

1. Create the membership values (fuzzify).

2. Specify the rule table.

3. Determine your procedure for defuzzifying the result.

First we have to fuzzify the data or create membership values for the data and put them into fuzzy sets. simply, we have to divide each set of data into ranges.

The following figure 27 shows the two stage(ZVT boost LCL-SRC ) with an voltage doubler and a Ffuzzy logic controller. At the input side a FUEL cell stack taken as the input source. And the figures 29, 30, 31 shows the input voltage, voltage across $\mathrm{V}_{\mathrm{ab}}$, output voltage $\mathrm{V}_{\mathrm{o}}$.

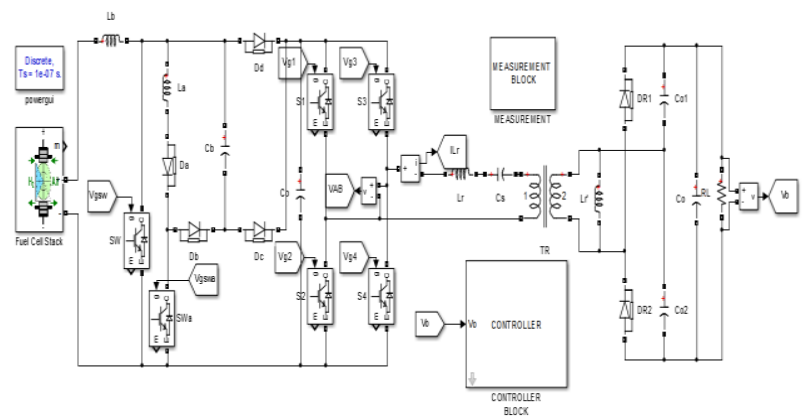

Fig. 27. MATLAB model of a FUZZY controller with voltage doubler

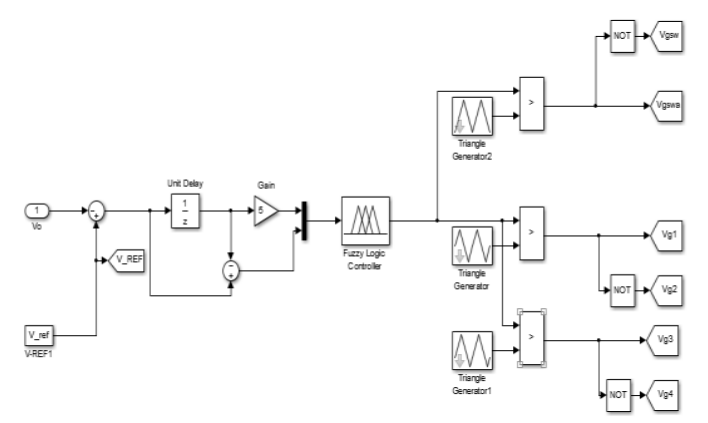

Fig. 28. MATLAB model of a subsystem of a FUZZY controller

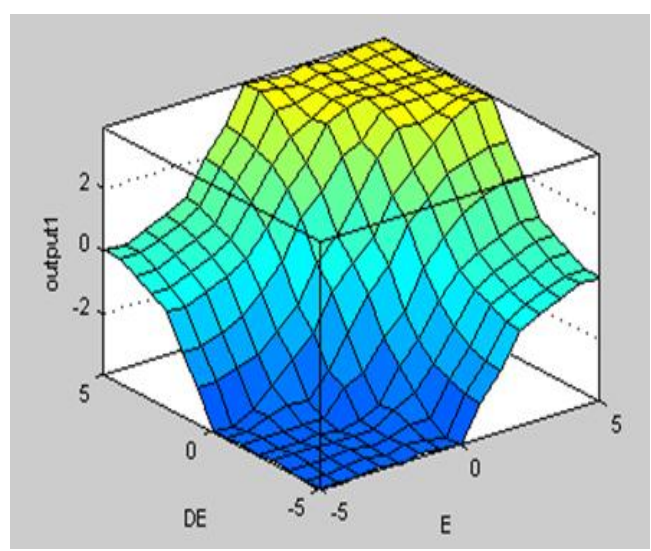

Fig. 29. fuzzy surface system

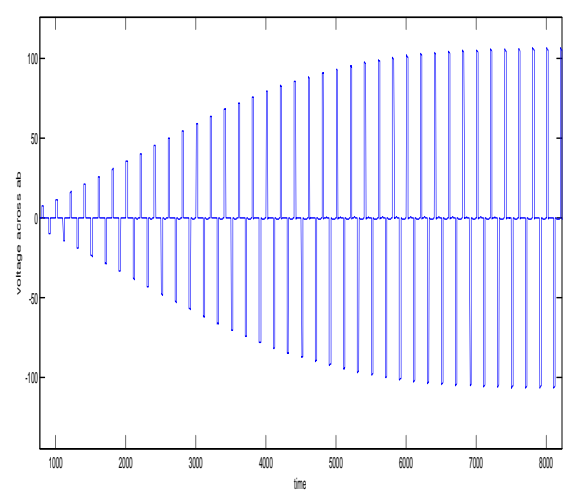

Fig. 30. Simulation result showing voltage $\mathrm{Vab}$

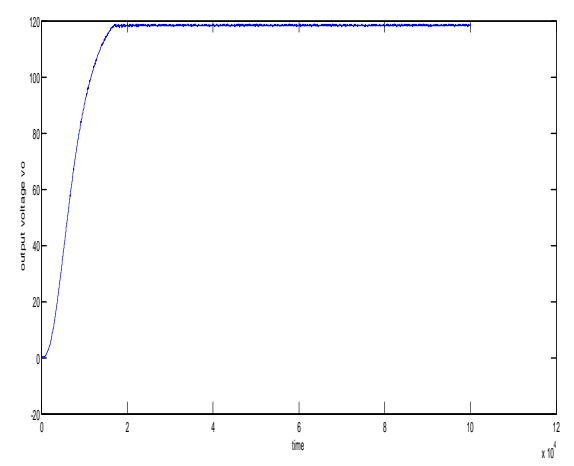

Fig. 31. Simulation result showing voltage Vab 


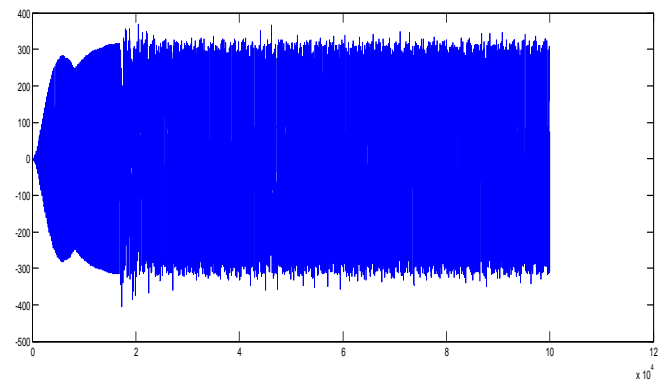

Fig. 32. Simulation result showing voltage $V a b$

In the above figure 27 a fuzzy logic controller was implemented with mamdani fuzzy inference type.when compared the results of PI and fuzzy controller from the figures 24and 30 it can be shown that even low voltage application also the fuzzy controller can reduce the output distortions.And also it maintains the ZVS for all switches reducing the switching losses.

fuell stack rating $=6 \mathrm{KW}-45 \mathrm{~V} \mathrm{DC}$

no of cells $=65$

voltage at $\mathrm{Vab}=100 \mathrm{v}$

output voltage $=120 \mathrm{~V}$

\section{CONCLUSIONS}

In this paper a fuzzy logic controlled DC-DC converter for an electrolyzer application has been implemented using MATLAB/simulink. Among available converter configurations it is shown that the a ZVT BOOST along with LCL -SRC converter is best one for the electrolyzer. To reduce the output distortions a PI controller was kept in order to reduce the steady state error. A voltage doubler introduced in the circuit acts as both rectifier and as voltage doubler .the simulation results are checked for both fuzzy and PI controller. It is shown that by using fuzzy logic controlled converter the conversion can be operated smoothly and efficiently for electrolyzer application compared to the other converters. And the output voltage range also doubled .

\section{REFERENCES}

[1] D. Shapiro, J. Duffy, M. Kimble, and M. Pien, "Solarpowered regenerative PEM electrolyzer/fuel cell system," J. Solar Energy, vol. 79, pp. 544-550, 2005.

[2] X. Zhang, H. S.-H. Chung, X. Ruan, and A. Ioinovici, "A ZCS full-bridge converter without voltage overstress on the switches," IEEE Trans. PowerElectron., vol. 25, no. 3, pp. 686-698, Mar. 201

[3] D. S. Gautam and A. K. S. Bhat, "A two-stage softswitched converter for electrolyser application," in Proc. Nat. Power Syst. Conf., Mumbai, India, 2008, pp. 524-528.

[4] A.K.S. Bhat, "Analysis and design of LCL-type resonant converter", IEEE Trans. on Industrial Electronics, vol. 41, no. 1, pp. 118-124, Feb. 1994.

[5] A.K.S. Bhat, "Analysis and design of a fixed frequency LCL-type series resonant converter," IEEE Trans. on Aerospace and Electronic Systems, vol. 31, no. 1, Jan. 1995, 125-137.
[6] Ahmadi, P., Dincer, I., Rosen, M.A., 2013. Energy and exergy analyses of hydrogen production via solarboosted ocean thermal energy conversion and PEM electrolysis. International Journal of Hydrogen Energy, $38 \quad$ (4) : $1795-\quad 1805$. [doi:10.1016/j.ijhydene.2012.11.025]

[7] Arriaga, L.G., Martinez, W., Cano, U., Blud, H., 2007. Direct coupling of a solar-hydrogen system in Mexico. International Journal of Hydrogen Energy, 32 (13): 2247- 2252. [doi:10.1016/j.ijhydene.2006.10.067]

[8] Y. Jang and M. M. Jovanovic, "A new family of fullbridge ZVS converters," IEEE Trans. Power Electron., vol. 19, no. 3, pp. 701-708, May 2004.

[9] H. Bodur and A. F. Bakan, "A new ZVT-PWM DCDC converter," IEEE Trans. on Power Electr., vol. 17, no. 1, Jan. 2002, pp. 40-47.

[10] R. Streit and D. Tollik, "High efficiency telecom rectifier using a novel soft-switched boost based input current shaper", IEEE INTELC Conf. Record, 1991, pp.720-726.

[11] Ferraro, "An overview of low-loss snubber technology for transistor converters," in Proc. IEEE Power Electron. Spec. Conf., 1982, pp.466-477.

[12] G. Hua, C. S. Leu, Y. Jiang, and F. C. Y. Lee, "Novel zero-voltagetransition PWM converters," IEEE Trans. Power Electron., vol. 9, pp. 213-219, Mar. 1994. 601-606, Nov. 1994.

[13] D. S. Gautam and A. K. S. Bhat, "A two-stage softswitched converter for electrolyser application," in Proc. Nat. Power Syst. Conf., Mumbai, India, 2008, pp. 524-528. 